\title{
THE OPEN SUBJECT AND THE HURTFUL WORLD: TOUCH AND OPENING UP THE POSTMODERN SUBJECT
}

\author{
PETAR BAGARIĆ
}

The appeal for a radical bodily and sensory engagement through fieldwork is based upon the idea that the body and senses permit an immediate experience that can help anthropologists experience and come to know the subject of their research in a direct manner. Legitimated by the phenomenological project of overcoming Cartesian dichotomies, bodily engagement promotes the idea that emotional and sensory openness to the world and the Other can help the subject avoid the supposedly distancing nature of modernist formed perception. Yet this idea, as I conclude on the basis of my own fieldwork and autoethnographic insights, is a symptom of a specific type of subject that emerged with postmodernity and expresses values and an ideology in accordance with the logic of late-capitalist Western societies.

Keywords: postmodernity, subject, phenomenological anthropology, body, tactile senses
Poziv na potpuni emocionalni, osjetilni i tjelesni angažman na etnografskom terenu koji su iznjedrile postmoderne antropologije poput antropologije tijela $i$ antropologije osjetila, temelji se na ideji da tijelo i tjelesna osjetila mogu pomoći antropologu da izravno doživi i spozna predmet svog istraživanja. Služeći se fenomenološkim konceptima razvijanima u svrhu razrješenja kartezijanskih dihotomija, paradigma potpunog tjelesnog angažmana podržava idejuo emotivnom i osjetilnom otvaranju spram svijeta kao subjektovom oslobadanju od modernističkih perceptivnih uzusa. Moja iskustva s etnografskog terena, kao i autoetnografski uvidi, dovode u pitanje takvu ideju pa zaključujem da je ona temeljno simptom postmodernog subjekta koji izražava ideologiju i vrijednosti karakteristične za društvo kasnog kapitalizma na Zapadu.

Keywords: postmoderna, subjekt, fenomenoloska antropologija, tijelo, dodir

\section{INTRODUCTION}

The turn to the body and senses in anthropology raised questions of how we perceive, represent, and use them in theory, as well as in everyday life. Anthropologists engaged in those turns, who were inspired by the phenomenological tradition, went further and proposed a new methodological approach: full bodily and sensory immersion in the field (see: Jackson 1983; Pink 2009; Stoller 2011.). With theoretical insights and methodological suggestions that plead for a bodily experiential and engaged approach to fieldwork, the anthropological quest for knowledge became a form of sensory undertaking. Such sensory and bodily immersion in the field, it is presumed, can provide the ethnographer with a direct and immediate perceptual experience that may transcend the cultural, social, or contextual boundaries between the researcher and the researched. Namely, as a part of a larger movement in the humanities, which ought to end the rule of Cartesian logocentrism, the bodily and sensory turns, strengthened with phenomenological concepts, tend to explore the possibilities of non-dualistic perception, which supposedly limits the anthropologist's cognition of the 
Other in a subject-object manner. The objectification of otherness is perceived from this perspective as an unwanted mental attitude that blocks our ability to fully experience and know the Other. It is also thought to limit our perception to a narrow aspect of existence that is susceptible to Cartesian-based forms of rationalization, which is reducible to a set of binary oppositions such as mind-body, individual-society, subject-object, and so on.

Although the heightened reflexivity of phenomenological anthropologies can easily be subsumed under the general critique of reflexivity in anthropology as an egoistic and narcissistic practice (cf. Bourdieu 2003) that perceives culture as a "warm bath" (Knibbe and Versteeg 2008) in to which the anthropologist can simply step in and out at will, the phenomenological paradigm of radically engaged fieldwork is, arguably, the only real methodological novelty that postmodern anthropologies have managed to generate (Al-Mohammad 2011).

My own attempt to use a warm bath methodology during my fieldwork in Zagreb in 2010 turned out to be unsuccessful. I wanted to explore the possibility of a non-dualistic and non-dividing perception of the Other via my body and my sense of touch and, for that purpose, I decided to take a course in Swedish massage. However, as I was slowly immersing myself in the practices associated with massage, I found that those features traditionally attributed to the abstract nature of the modern subject and criticized as alienating effects of modern ideology-distance, control, and containment-came to me spontaneously and effortlessly. My body did not become one with other bodies. My sense of touch did not overcome and did not bypass subject-object perceptions. Thus, the following question arose: was my attempt to know others immediately, through body and touch-an attempt that would allow me to overcome the Cartesian illusion of separation-an attempt to meet an ideological dictum? A dictum that replaced the modernist call for individual self-control and detachment with an approach that is more suited to serve the needs of the specific postmodern condition? It is a dictum that demands incessant "staying in touch." It prohibits detachment and distancing, and it also requires of the subject the ability to flow and change. The same dictum requires open bodily boundaries and total sensory immersion in one's surroundings in order to allow for the unobstructed flow of various stimuli and messages that inhabit the world of late capitalism (Livingston 1998). This dictum calls for fast and easy adaptation of skills and habitual structures through which individuals meet the demands of the insecure contemporary job market (Archer 2010).

But if the body and personality are to follow such dictums, some ontological assumptions regarding the subject's embodiment and also its tactile predispositions concerning interaction first need to be remade. The idea of a world that hurts the subject, one of the key features of Western embodiment since Greek antiquity, first needed to be reshaped in postmodernity so that immediate contact with exteriority may cease to represent a threat. The subject had to be drawn into the world via its body and a new awareness of touch had to be forged. The intimate aspect of touch is stressed, while basic trust in the world is required and encouraged. That specific trust — as I will argue in depth later-is dependent 
upon the contemporary social context of Western societies of late capitalism, which provides for the basic physical and emotional integrity of its members.

I examine the ways in which the subject's boundaries and their articulation through notions related to touch and touching were formed in order to secure the subject's closure or its subsequent opening to the world. The importance of touch in this context is based upon the idea that touch is a sense that has the capacity of allowing the subject an immediate relationship with the world and other subjects. This idea has been a continuous object of philosophical inquiry ever since Aristotle (Derrida 2005). It is the backdrop against which the sense of touch has been evaluated, conceived, and experienced. The philosophical traditions taken into account in this article are the ones that, in my opinion, express, elaborate, and develop ideas about subjectivity in ways that support established orders and ideologies, or those that are yet to come. Various literal, historical, and anthropological works are evoked in order to further explain and describe the theses presented in this paper.

\section{HOW I FAILED AT PHENOMENOLOGY}

The opportunity to approach a part of our existence that permanently underlines all aspects of our lives and the potential to acquire a language that would be able to describe and give meaning to all those subtle tactile cues we exchange in everyday situations, mostly without recognizing them, fueled my enthusiasm as I attended the first, introductory lectures in human anatomy and physiology at my Swedish massage course. After an intense period of lectures over a period of one month, an exam was held and I came closer to the prize-two months of practical instruction during which I was going to massage and be massaged on many occasions. My academic interest was in the practice of touch as a sense that avoids perception positioned within subject-object relations and possesses the "capacity to reach beyond the individual toward other bodies, effectively drawing them into proximity" (Paterson 2007: 13).

Although I tried to bypass abstracting and other "detaching” mental processes via the sense of touch, my previously acquired knowledge remained. We had learned the names of the muscles, bones, and joints; their appearance, function, and position. When I was rubbing someone, I was massaging those muscles. There they were, under my fingers: gluteus, latissimus dorsi, gracilis, and so on. No matter how much I tried to concentrate on the tactile stimuli in order to avoid making presumptions and no matter how hard I tried to feel the client directly in a non-objectifying manner, a subject-object relationship was firmly established even on the corporeal level. When I was massaging, I was a subject. When I was being massaged, I was an object — and if the person massaging me was skillful, I didn't mind being objectified at all. The disappearance of the distance between the other person and me did not abolish the subject-object divide; on the contrary, it intensified it. The Cartesian dichotomy remained, albeit in a completely embodied form. 
What I also noticed is that the body as object (or objectified) in the massage process, although passive, was not helpless. There was some kind of nonverbal understanding between bodies. Although all of my classmates would patiently lie down on the massage table and allow me to try out each technique I had learned, during sessions that sometimes lasted for two hours, I did not always feel that my access to someone's interiority was granted. Bodies seemed to have their own ways of granting access to others and, also, of denying it.

Mirko was thirty-five at the time. He was a homeopathic therapist who wanted to master Swedish massage. As I massaged him, I felt as if he was hiding from me. It was like his body turned into a system of dead-end streets. I simply could not get to a point where I could say: "Here, done." It was as if I was being mocked or played with: I could try as much as I wanted, but that body would not give me the satisfaction of a job well done. Mirko was not satisfied either. Several times, he tried to explain to me what would suit him better and where I made mistakes. However, every time I massaged him I felt the same: that with him, I could not make any progress. When the moment came for him to massage me, it felt terrible. He did nothing wrong technically, but it still felt wrong. My body wanted me to stop him. I did not. Instead, I was conscientiously playing my role of the client and I was patiently waiting for him to do a whole-body massage. Not only that: I also consciously resisted my body's need to close itself to the unpleasant stimuli I experienced throughout the massage. I did my best to take the opportunity to pay attention to the tactile sensations I was receiving in order to make good ethnography out of it later. It was very unpleasant. Mirko would check out the effects of his moves every now and then with me while massaging. Yet, once I figured out that no matter how he did it I was still going to feel bad in the end, I just kept telling him that it was all okay.

For the next three days after that massage I felt sick and ill. It was as if my body was alien to me. Once he massaged my leg while another classmate massaged the other leg. Afterwards, the leg Mirko massaged hurt me for days: I could barely stand on it. I checked with other classmates, and it turned out that other people were generally satisfied with the way Mirko massaged them. On the other hand, I was generally satisfied with everyone else's massage except for Mirko's. It simply did not work between him and me. My body wanted to distance itself from him, my spirit wanted to hide, and my attempts to be fully engaged and aware while being touched by him had painful consequences.

Although I was willing to overcome the boundaries of a modern ideology of subjectivity, and open my body to the Other, my body was not. It continuously searched for a way to close itself to outside stimuli and to block others approaching its deeper layers. My faith in a world of the body and senses that would oppose the logic of the modern subject was strong, but my body resisted it. It was not ready for postmodernity.

The paradigm of practical engagement in anthropology is usually rooted in an idea of a pre-discursive body completely and inseparably joined with the world and with others (Al-Mohammad 2011). Such a unity of the subject and the world, it is assumed, can be grasped intuitively in the moment in which a person lets go of his or her inherited Cartesian 
mental habits. Those habits which incline the subject to perceive reality in the form of a subject-object and mind-body division are usually understood in postmodernity as an effect of a disembodied modern cogito that cannot be demonstrated as existing on an empirical level. My personal fieldwork experience led me in the completely opposite direction. The immersive experience I gained through fieldwork confirmed the embodied reality of classical Cartesian dichotomies. The presumed pre-discursive unity, which supposedly should be intuitively graspable through bodily immersion, was out of my reach.

\section{MODERNITY: THE CLOSURE OF THE SUBJECT}

The attempt to delineate certain features of the subject throughout history is somewhat paradoxical, bearing in mind that the subject itself is not a coherent and lasting concept, and that it acquired (and still does) divergent forms within different epochs, cultures, or specific systems of thought (Williams 2001). Notwithstanding, the subject we have in mind still has traces of its modernist origins (ibid.). The modern subject arose in a specific context, in which a medieval picture of the world had already completely dissolved, and new modernist paradigms still had not procured an unquestionable, ruling position for themselves. At times of epochal changes, the order that enables a phenomenon's stable meaning inevitably falls apart. In such a period, objects cannot speak for themselves anymore, and the world needs to be reinvented in order to provide a stable web of meaning.

As Adorno (1973) reminded us, this is at least partly what happened in the eighteenth century. It is in this light that we need to observe Immanuel Kant's philosophical attempt to derive the world and its order from the perspective of the subject's consciousness. Kant's subject is an individual who does not accept any form of exogenous conditioning for himself/herself, and relies exclusively on his/her own mind in an attempt to specify the nature of the permanent philosophical subjects of inquiry: truth, goodness, and beauty. The society and knowledge that the Enlightenment strived to establish could not rely on a metaphysical authority of one god who would proscribe and secure certainty of knowledge and morals. Instead, the Enlightenment project tried to adjust the social world according to the rules of scientific reason, and it needed an individual capable of relying solely on his or her mind with regard to action and cognition (Kalanj 1994). This is why the basic principles of knowledge and morality had to be reinvented as the pure form of a subject's consciousness. Once established, those principles could serve as the foundation of modern political and scientific projects. Yet those projects, as well as the principles upon which they were founded, were often mutually contradictory: cognitive acts were still carried out in an objectifying manner and, as such, they were at odds with ethical principles that forbade the objectification of human beings, who were understood to be an end in themselves. The differing nature of the ethical and epistemological Kantian systems prevented them from acquiring a unifying ontological foundation, and their unity had to be assured 
through a unique, common space within the subject's interior. The subject was only able to appropriate the attributes of morality, freedom, and enlightenment by containing them within its own boundaries. While it must be noted that Immanuel Kant was not the only philosopher concerned with the problem of the subject during the Enlightenment, his work may be viewed as the most successful and most important attempt at philosophical deliberation concerning that theme (ibid.).

The rational individuals envisaged by Kant (1996/1798) had to direct their skeptical attention towards the external world and, in their inwardness, they had to practice control in order to keep their integrity:

To scrutinize the various acts of the imagination within me, when I call them forth, is indeed worth reflection, as well as necessary and useful for logic and metaphysics. But to wish to play the spy upon oneself, when those acts come to mind unsummoned and of their own accord (which happens through the play of the unpremeditatedly creative imagination), is to reverse the natural order of the cognitive powers, since then the rational elements do not take the lead (as they should) but instead follow behind. (Kant 1996: 17).

The rational subject thus needs to establish itself as the instance of consciousness distinct from the contents of that same consciousness. This separation from the content of consciousness is required because the content, once presented to a subject in an empirical manner, potentially threatens the coherence of the subject. That is why in his Critique of Practical Reason Kant validates an action that is grounded solely upon the pure form of the mind as the only legitimate moral action. Distrust towards actions fashioned by utilitarian reasons, as opposed to actions that arise from the mind's pure form, is, in fact, an expression of distrust towards actions caused by external reasons. Such reasons are potentially contaminating for the self, because all actions guided by external motives are inherently unable to contribute to the subject's autonomy and freedom. Further, Kant's teachings about the nature of cognition may be read as a schema of the internal handling of ideas and notions that ought to provide a specific internal design of the subject.

Such a subject design was arranged within the firm boundaries that separated the subject's inwardness from the outside world. Because the bodily senses represent the subject's connection to the world - the openings through which the world could pour in - they had to remain outside and be kept under control in order to protect the subject's coherence. The subject's attitude regarding the senses is merely a reflection of its insistence on its autonomy, ensured by firm boundaries towards the outside world, and realized through firm control over the senses and internal impulses. The question of sensory perception and cognition also raised problems of control over that boundary. The individual was threatened by the possibility of being contaminated by external content and, since the body was the arena of 
battle between external and internal principles, it was necessary for the subject to establish control over the content of sensory experience. This is why Kant, after analyzing the conditions of knowledge in the Critiques, also had to present its technical conditions in his Anthropology from a Pragmatic Point of View (1996/1798). Those conditions are: exercise, discipline, and having a correct relationship to the senses.

In Anthropology, reason was perceived as the subject's sanctuary and it was expected to control the senses: "The senses do not control the understanding. They, on the contrary, offer themselves to the understanding only for the sake of being put to work in its service" (Kant 1996: 30-31). The ability to distinguish between outer and inner spheres of existence, as well as the possibility of controlling one's ideas and senses, is very important to Kant. Without this control, the senses are free to "bomb" the inner world with external content and therefore jeopardize the autonomy of the rational subject. This should be taken into account in the interpretation of why Kant's idea of a closed subject values the sense of sight so highly. Unlike touch, sight allows for the subject to remain detached:

The sense of sight, while not more indispensable than the sense of hearing, is, nevertheless, the noblest, since, among all the senses, it is farthest removed from the sense of touch, which is the most limited condition of perception. Not only does the sight have the greatest radius of perception of space, but its sense organ is also physically least involved." (Kant 1996: 43; my emphasis)

This is also probably one of the reasons why vision later gained a privileged place in the Western hierarchy of the senses. In addition to being deemed as useful, it also became a metaphor of impersonal knowledge because it most directly allowed for the subject's detachment from the object perceived. Vision was viewed as a sense that allows the subject to voluntarily open and close itself to the world. Touch, precisely because it was perceived as an involved sense, was not highly regarded by Kant (1996/1798).

The modernist aversion to touch, initially enacted in the ideal of the rational subject, was supported by medical sciences later in the nineteenth century when touch came to represent a dangerously effective way of transmitting contagious diseases. According to Stallybrass and White (2005), the British middle class of the nineteenth century was obsessed with avoiding physical contact. For the bourgeois, they claim (ibid.), balconies became a necessary addition to many buildings because they allowed members of higher classes to watch the street spectacle while avoiding the risk of contact with dirty, poor people. The bodily boundaries of the modern subject were established as sacred, whereas touch became an unpleasant reminder of the individual's vulnerability:

There is nothing that man fears more than the touch of the unknown. He wants to see what is reaching towards him, and to be able to recognize 
or at least classify it. Man always tends to avoid physical contact with anything strange. In the dark, the fear of an unexpected touch can mount to panic. Even clothes give insufficient security: it is easy to tear them and pierce through to the naked, smooth, defenseless flesh of the victim. All the distances which men create around themselves are dictated by this. (Canetti 1978:15)

Further in the book "Crowds and Power," Elias Canetti described the ways in which subjects free themselves from the fear of touch by gathering in crowds. It is important to bear in mind that it is not a need for touch, but rather a fear of touching that Canetti's subject is satisfying through his or her gathering in crowds. Through immersion in the crowd, the individual body's boundaries are dissolved and a threatening outsideness, or exteriority, is relocated beyond the boundaries of the crowd, so that the individual can let go of his or her fear of touching other individuals who are also part of the crowd.

\section{POSTMODERNITY AS IMMERSION IN A STREAM}

The end of the modern project and the disappearance of "grand narratives" in the second half of the twentieth century removed certain stable reference points that were able to help us grasp the meaning of things. In spite of Kant's proposition, we are unable-at this historical moment, at least—-to derive the world solely from our minds. The fall of rationalistic supremacy has left us with the myriad of sensations and processes that cannot be subsumed under stable, universalistic hierarchies:

A world where we once knew ourselves in terms of values and identities has given way to the uninterrupted intensities of elation and grief, triumph and trauma, loss and achievement; birth, death, survival, crime, consumption, a career are all now pretexts for emotion. Things and events are now understood on the level of the pulsing, breathing, feeling individual self. (Mansfield 2000: 2)

Deprived of a metaphysical foundation in the form of universal human nature, the new subject would try to establish itself through its relations with others and through its everyday existence. One of the key thinkers of postmodernity, Zygmunt Bumann (1993), claims that contemporary morality must be re-personalized and separated from social codes. He grounds his beliefs in the philosophy of Emmanuel Levinas (1969), who posits the core of subjectivity as being in relations established with the Other. Levinas (ibid.), in fact, believes that ethics in the essential sense precedes metaphysics and that ethics enables the subjectivation of the ego through the veneration of the Other's subjectivity. The subject 
shaped by Levinas's thought is a category that emerges in an ethical and bodily relation towards the Other, while the ethically unwanted characteristic of objectification is avoided by a reliance on the bodily and sensory aspects of experience: "Sensibility is not a fumbling objectification. The senses have a meaning that is not predetermined as objectification" (ibid.: 187-188).

Just as the postmodern epoch has a different form from the modern one, it also requires a different kind of subject. An appropriate form for the subject is needed because it is its function to enable various political, ethical, and epistemic projects to become natural parts of the self. If the process of their implementation turns out to be successful, these projects will emerge as self-evident parts of individual consciousness. For example, inside a modern constellation it was very natural for a person to experience directly, and in a self-evident manner, a separation from the world as well as to accept the notion of having his or her own body as a fact. In a postmodern constellation, on the other hand, the direct experiential fact would become the claim that I am the body and that I am indistinguishable from the world. While the Cartesian separation between mind and body, and consciousness and world, helped the modern subject in its attempts to objectify the outer world, such divisions and objectifications would become utterly undesirable in postmodernity.

The postmodern subject, unable to achieve contact with the world and the Other through universalistic transcendental categories, would try to accomplish an immediate contact. The solution for the problem of an immediate perception of the Other, which turned out to be an insolvable problem within traditional phenomenological thought (Pivčević 1997), was offered by Merleau-Ponty (2002/1945) and his concept of the embodied subject: "I am my body" (ibid.: 231). The role of Merleau-Ponty's idea is to overcome the Cartesian mind-body dualism through the embodiment of the subject, and to achieve the desired direct access to the outside world and others via an ontological equation realized through the subject's body. Such an attempt redefined the role of the senses as well as their hierarchy. Touch, once avoided and regarded as abhorrent, becomes the basic and favorite sense of this new paradigm. This is especially the case within philosophical phenomenology, in which the sense of touch became a sort of basic sense that enables the subject's direct perception of itself (cf. Derrida 2005). Touch in phenomenology, as Derrida (ibid.) argues, is determined by several contours already outlined in Husserl's work: directness, intuitiveness, instantaneity, and the possibility of bodily self-referentiality (ibid.: 171). It is a sense through which the postmodern subject can experience the materiality of its environment as something immediately given, and simultaneously experience itself as a body. The sense of touch becomes the key perceptual condition for such a subject. Namely, the basic phenomenological presumption is that the subject, while it touches the object, simultaneously touches itself.

Perception in the form of touch implies the integration of being and knowing and their subsuming under a tactile denominator that opens up the subject for an immediate being-with-the-other. If such a perception is to be realized, it requires all categories to be 
articulated in a form of immediate bodily recognition. Society, community, language — all those once abstract categories will be expressed in a bodily, tactile code:

Before being spoken, before being a particular language or signification, before being verbal, "language" is the following: the extension and simultaneity of the "with" insofar as it is the ownmostpower of a body, the propriety of its touching another body (or of touching itself), which is nothing other than its definition as body. (Nancy 2000: 92)

The specific nature of perception shaped through touch is a key site where we can grasp the full scale of change that happened to the subject and the world in the transition from modernity to postmodernity. Namely, ways of perceiving indicate certain preferences regarding individuals' willingness to open or close themselves to the Other in a certain way. Unlike the modern subject, the postmodern one chooses to touch and to be touched. The Croatian philosopher and writer Andrea Zlatar (2010), for example, explains disgust at physical contact in an everyday urban environment as an effect of a social hygiene matrix. Although she recognizes the possibility that aversion to touch may be a result of endangered personal boundaries, she nevertheless identifies a modernist symbolic system as the main cause of repression regarding physical contact in everyday life situations.

Repressive social norms inform us of in which everyday situations touching is "inadequate and inappropriate." Imagine that you wish to kiss a clerk at a bank window. If you have a "personal banker," of course, you'll shake his hand at the beginning and the end of the meeting. But-even if you know him privately - you will not try to kiss him in the context of the business meeting. (Zlatar 2010:20)

While she does not further explicate the urge to touch, and she treats it as something self-evident, something that would belong to the subject's bodily nature; she elaborates it as something directly opposed to the phenomenon of disgust and aversion, which is, on the other hand, presented as epiphenomenal and socially determined. While it was very natural for Canetti's individual to be afraid of touch, such a fear in Zlatar's view is but a residue of modernistic socialization. Whereas disgust is culturally conditioned, the urge to touch something is supposedly spontaneous. The willingness to touch is characteristic of a type of subjectivity that continuously gains strength and recognition in the postmodern era. But for this willingness to be realized, the very nature of touch-and primarily its capacity to hurt-first needs to be forgotten. 


\section{BOY MEETS WORLD - WHEN I WAS OPEN}

The methodological concept of the self as the "incubator of ethnography" (Collins and Galliant 2013:11) allows us to approach and reflect on our biography and our past experiences as one of the key ingredients constituting the background to our fieldwork and research experience. Although it cannot (and it should not) be viewed as a guarantee of authenticity of ethnographers' statements (Dyck 2013), it does, nevertheless, help us to position the ethnographer's persona more clearly because, as Lynette Šikić-Mićanović (2013) points out: "Our personal experiences and memories as well as our temperaments and personalities inevitably influence our choice of research sites, themes, design and theoretical approaches" (ibid.: 57). By taking this into account, I shall now offer a brief section of my biography in which my self, my body, and the world came into a close and intense interplay that significantly determined my later views about the problems dealt with in this paper. This interplay took place during a period I spent as a refugee in the Croatian town of Split.

In the spring of 1992, war broke out in Bosnia and Herzegovina and I fled, together with my family, from Sarajevo, which was already under siege by the JNA (Yugoslav National Army) when the forces of the "Serbian Republic" of Bosnia and Herzegovina joined their forces in the project of realizing a "Greater Serbia." We took shelter with my father's relatives in a village located in Western Bosnia and Herzegovina from which both of my parents originally came. From there, my parents travelled to Germany with my sister, while I was left in the Croatian city of Split to finish my secondary school education. Large parts of the neighboring Croatia were also occupied at the time by the army of the "SAO Krajina," ${ }^{2}$ while Croatia was ruled by a nationalistic party called HDZ (The Croatian Democratic Union).

At the time, Split was a chaotic place. Frequent blackouts would leave one in total darkness when traversing public spaces. In the streets, there were depressed-looking soldiers, waiting for the buses that would take them to the battle lines, or, rather, drinking after they had already spent some time on the battle field. The military police were capturing men who avoided being conscripted in the army and they were generally feared and avoided. Hostility towards Serbs was institutionally promoted and supported, and people of Serbian ethnicity usually hid their ethnic background. I was fifteen at the time and I stayed in a dormitory for secondary school students.

Our tutor in the dormitory bragged to a close friend of mine that the dormitory management had succeeded in "getting rid" of the dormitory residents of Serbian origin and that next year they would "get rid of Muslims, as well." My friend was also a Serb, but

1 "Greater Serbia" is a popular term for the nationalist project of politically and militarily uniting all Serb-populated areas in the former Yugoslavia into a single state.

2 A Serbian territorial and military entity in Croatia, which existed between 1991 and 1995. SAO Krajina never managed to gain international recognition as a political unit. 
our tutor did not know that and not a single one of us living there would tell him that. Serbian families were often evicted from their apartments, which were then often taken over by members of the Croatian army. ${ }^{3}$ The nascent Croatian national identity was being articulated through an identification with Catholicism and also via the "new" Croatian language, which was linguistically "purified" in order to be as different as possible from Serbian. No one was really sure how to speak proper Croatian and Croatia became a land of "language sticklers" (Lucić 2009), in which everyone could correct anyone for not using “proper” Croatian (Kapović 2010; Kordić 2010).

On one occasion the dormitory tutor had a conversation with me about the importance of sticking to my Catholic faith—since I am a Croat—and also about the importance of avoiding other religious systems, and particularly Jehovah's Witnesses, with whom I had some contacts at the time. I quickly figured out that I must hide some of the things I thought and felt, and not just from the tutor: practically anything could have been judged by almost anyone. Everyday conversations were easily sidetracked into risky questions about family lineage and place of origin, and one could easily find oneself in a lower or even threatened position in front of the interlocutor.

I was penniless, alone, and afraid. The boundaries of the small and predictable life that I previously had in Sarajevo broke abruptly, together with its patterns of communication. My parents, who used to secure and mediate the area between me and the world, were suddenly out of reach. The skills and habits that once helped me handle my childhood life did not work anymore. It was as if an essential membrane woven of social and family threads that had once enveloped me ripped apart, and the world poured in.

I underwent a crisis that probably would have required some professional help, but because I knew nothing about the possibility of psychological assistance or therapy at the time, I went through it more or less alone. I had bouts of nausea during social encounters and I found it hard at times not to throw up while watching people acting as if everything was normal and the way it should be. Every impulse from the outside world moved directly into me-every sound and color, each word and facial expression. Metaphorically it felt as if I had no skin, and my real skin also reacted to that experience, resulting in my developing vitiligo, ${ }^{4}$ which quickly spread around my eyes.

Because I lacked "skin" as a means of protection from the outside, I tried to develop an armor through my muscles. I had a book about karate and I started studying it with diligence. I trained on a daily basis. I practiced punching the bag and hitting the metal fence and wall with my forearms and fists in order to harden them. My body was constantly tense, I had insomnia and I was engaged in an incessant process of ruminating on anything and everything that would come into my mind or catch my attention: sex, money, the nation, politics, gays, parenthood, myself. I would be able to fall sleep regularly only a few years

3 For more details about the evictions in Split, see: Janković and Mokrović 2011; Nizich et al. 1995.

4 A skin condition in which certain portions of skin lose their pigment. 
later, when I consciously learned to close my mind to the world and induce sleep at my own will. The crisis eased throughout the four years of my schooling in Split, largely due to my adopting new routines that became suitable for my new life and for my new economy of attention. The world around me was still rather chaotic and I was aware of that, but after some time, I realized that all of that chaos did not need $m y$ constant attention. It was not of my concern. I could detach. I became able to get acquainted with various positive and negative pieces of information, while remaining at a distance. I learned to hold the world at arm's length.

Insomnia and psychological crisis combined with daily training sessions made my appearance somewhat scary and intimidating, which discouraged bystanders from trying to initiate contact with me. It seemed as if the world and people around me were at a constant distance from me, which felt fine at the time. I engaged with the world and others through full contact, without the usual social and legal restrictions and without the possibility of sheltering myself and I did not like it; it was hurtful.

At this moment I found myself exploring the possibility of researching the immediacy and particular aspects of tactual perception in ethnography, almost twenty years after the war had finished. My life in Zagreb had already become a routine equilibrium of pleasant and unpleasant moments. Croatia was on its way to becoming an EU member and society was adopting norms and ethics perceived or at least represented as "European". Making judgments about other people's choices was slowly, but surely becoming a socially undesired behavior and except for the occasional outbursts from representatives of the political right, few people were questioning people's ethnic or ideological family background any more. I was surrounded by social networks, products available to consumers in advanced capitalist societies, accompanied by an ever-increasing discourse of cosmopolitan tolerance towards the Other.

\section{HOW POSTMODERNITY TOOK THE PAIN AWAY}

The ability to undergo a perceptual and sensorial closing away from the world and from others is a basic way for the subject to protect itself from hurting and the pain that may emerge in various kinds of immediate contact. The specific hurt that emerges as an effect of immediacy is a steady fixture of bodily sensations since at least antiquity. Moreover, it seems that the very ability of the body to be hurt is one of its determining constituents. Namely, as the historian of medicine Brook Holmes (2010: 2) claims, the phenomenon of the living body, which emerged in ancient Greece, was originally based upon the idea of a world that operates on the subject in a harmful way.

The interplay of world and body through hurt and harm was carried forward into the Middle Ages. The religious zeal of the time called upon people to join God and to be open to His grace and, although the subject showed a good will to open his whole body 
to it, this opening did not circumvent the pain that came along with it. Tactile language was used to simultaneously express pain and God's presence (Classen 2012: 29). With the body of the suffering Christ established as the crucial object of devotion and religious meditation in the twelfth century (Largier 2008:374), man was called upon to relive all Christ's physical and emotional pain, so that the subject needed to open a hurtful fissure in his or her boundaries in order to receive God's grace.

That fragile body and hurtful touch persevered in modernity as well, and these notions continued to permeate the subject that emerged in Enlightenment philosophy. The emergence of the modern subject was supported by social norms that had been developing since the Middle Ages which determined the subject's economy of affects, secretions, and table manners (cf. Elias 1996). The logic of those norms gradually led to the hyperregulation of touch and touching in professional and public environments (Piper and Stronach 2008; O'Malley Halley 2009) so that at the end of modernity the subject found itself in a social context wherein everyday contact with others was sporadic and suppressed. The hyperregulation of contact is the specific social, cultural, and sensory background upon which the subject of postmodernity emerges, together with its intimate values. However, it does not emerge in spite of this, but precisely because of it, although various authors advocating for postmodern sets of values (e.g. Zlatar 2010; Stoller 2011; Jackson 1983) express them as a reaction to and a critique of such social determinants. Namely, the rules regulating accepted norms of bodily behavior in the West are but a part of a legal and cultural environment greatly concerned with the protection of individual integrity. The acknowledgment of different forms of violence that may threaten the subject is at the base of the whole, essentially modernistic system of norms and bans that protect the subject's life and health, but also financial investments, personal opinions, religious beliefs, or sexual orientation. The level of protection that individual existence enjoys in the West today is, indeed, somewhat of a historical and geographical curiosity. But such a specific cultural and historical situation, in addition to the experience of existence within relatively prosperous societies that are not endangered by wars and other immediate existential threats, and which also protect their citizens from one another through myriad strict rules and boundaries, has undergone a certain ontologization in the meantime. The safety of the postmodern subject is often a neglected feature, and yet it is at the very core of its opportunity for painless bodily openings. When anthropology advocates for fieldwork based on the presumption of total sensorial engagement, the ultimate result is a problematic one, because it may be concealing more than it is disclosing. When, for example, Michael Jackson—a respected anthropologist and one of the champions of the bodily turn in anthropology—advocates for radical bodily engagement in fieldwork (1983), he forgets to mention his own privilege of exemption within the Kuranko village in Sierra Leone, which secures him the choice of daily activities he is going to take part in. Although he is particularly interested in the logic of painful and mutilating initiation rites in the village, he has not decided to subject himself to those. The dictum of the bodily opening that he advocates in his work needs 
to be decontextualized and separated from the threatening fieldwork details in order for it to become universal.

Although the rhetoric surrounding the postmodern subject has metaphysical ambitions-it advocates for the subject's return to the world and immediate contact with others-it can neglect the pain that prevents the subject's opening to the world through the process of the world's particular design. Namely, the world of Western postmodernity is socially produced to suit the needs of an individualized subject. Since the world was designed as a subject's construct, its hurtful otherness is thus canceled and immediate threats are removed. Whereas the Western subject of postmodernity already has a very intricate and firm level of legal and social boundaries at its disposal, it can let go of its bodily and emotional boundaries, and it can advocate a program of bodily and affective openings. The call for bodily and emotional opening may doubtless be quite appealing and useful, both within and outside academia. But when it becomes a dictum, when it aspires to reach the status of a metaphysical truth that subjects reality to its own logic, then it is, as asserted by Hannah Arendt(1966), not a mere idea any more, but an ideology.

Or, to follow Ron Broglio's (2008) conclusion on the Heideggerian subject, the promoted openness and empathy easily then become the subject's patronizing feature that ignores the painful and violent aspects of the nature of both reality and the Other.

\section{REFERENCES}

Adorno, Teodor V. 1973. Philosophische Terminologie: Zur Einleitung. Frankfurt am Main: Suhrkamp.

Al-Mohammad, Hayder. 2011. Less Methodology More Epistemology Please: The Body, Metaphysics and Certainty. Critique of Anthropology 31: 121-128.

Archer, Margaret S. 2010. Routine, Reflexivity, and Realism. Sociological Theory 28: 272-303.

Arendt, Hannah. 1966. The Origins of Totalitarianism. New York: Harcourt, Brace \& World.

Bagarić, Petar. 2011. "Razum i osjetila: fenomenološke tendencije antropologije osjetila." Narodna umjetnost 48 (2): 83-94.

Bauman, Zygmunt. 1993. Postmodern Ethics. Oxford: Blackwell.

Bourdieu, Pierre. 2003. Participant Objectivation. The Journal of the Royal Anthropological Institute 9 (2) 281-294.

Broglio, Ron. 2008. Heidegger's Shepherd of Being and Nietzsche's Satyr. New Formations 64: 124-3.

Canetti, Elias. 1973. Crowds and Power. New York: Continuum.

Classen, Constance. 2012. The Deepest Sense: A Cultural History of Touch. Illinois: University of Illinois Press.

Collins, Peter and AnselmaGallinat. 2013. The Ethnographic Self as Resource: An Introduction. In: Peter Collins and Anselma Gallinat (eds.), The Ethnographic Self as Resource. New York and Oxford: Berghahn Books, 1-22.

Hrvoje, Čargonja. 2013. Bodies and Worlds Alive: An Outline of Phenomenology in Anthropology. Studia Ethnologica Croatica 25: 19-60. 
Derrida, Jacques. 2005. On Touching Jean Luc Nancy. Stanford: Stanford University Press.

Dyck, Noel. 2013. Remembering and the Ethnography of Children's Sports. In: Peter Collins and Anselma Gallinat (eds.), The Ethnographic Self as Resource. New York and Oxford: Berghahn Books, 150-164.

Elias, Norbert. 2000 (1939). The Civilizing Process: Sociogenetic and Psychogenetic Investigations. Oxford: Blackwell.

Heather, Piper and Ian Stronach. 2008. Don't Touch. London: Routledge.

Holmes, Brooke. 2010. The Symptom and Subject: The Emergence of the Physical Body in Ancient Greece. Princeton: Princeton University Press.

Jackson, Michael. 1983. Knowledge of the Body. Man 1:327-345.

Janković, Vesna and Nikola Mokrović (eds.). 2011. Antiratna kampanja 1991-2011: Neispričana povijest. Zagreb: Documenta - centar za suočavanje s prošlošću.

Kalanj, Rade. 1994. Modernosti napredak. Zagreb: Antibarbarus.

Kant, Immanuel. 1996 (1798). Anthropology from a Pragmatic Point of View. Carbondale: Southern Illinois University Press.

Kant, Immanuel. 2002 (1781). Critique of Practical Reason. Indianapolis: Hackett Publishing Company.

Kapović, Mate. 2010. Čiji je jezik. Zagreb: Algoritam.

Knibbe, Kim and Peter Versteeg. 2008. Assessing Phenomenology in Anthropology. Critique of Anthropology 28 (1): 47-62.

Kordić, Snježana. 2010. Jezik i nacionalizam. Zagreb: Durieux.

Largier, Niklaus. 2008. Medieval Mysticism. In: John Corrigan (ed.), The Oxford Handbook of Religion and Emotion. Oxford: Oxford University Press, 364-379.

Levinas, Emmanuel. 2011. Totality and Infinity: An Essay on Exteriority. Pittsburgh: Duquesne University Press.

Livingston, Susan. 1998. Touch-Sensitive: Cybernetic Images and Replicant Bodies in the Post-Industrial Age. PhD diss., University of Warwick.

Lucić, Predrag. 2009. Sloboda je jedino što me zanima. Peščanik, January 17. http://pescanik.net/ sloboda-je-jedino-sto-me-zanima/

Mansfield, Nick. 2000. Subjectivity: Theories of the Selffrom Freud to Haraway. St Leonards: Allen \& Unwin.

Merleau-Ponty, Maurice. 2005 (1945). Phenomenology of Perception. London: Routledge.

Nancy, Jean-Luc. 2000. Being Singular Plural. Stanford: Stanford University Press.

O'Malley Halley, Jean. 2009. Boundaries of Touch: Parenting and Adult-Child Intimacy. Urbana: University of Illinois Press.

Paterson, Mark. 2007. The Senses of Touch Haptics, Affects and Technologies. Oxford and New York: Berg.

Pink, Sarah. 2009. Doing Sensory Ethnography. Los Angeles, London, New Delhi, Singapore and Washington DC: Sage.

Pivčević, Edo. 1997. Na tragu fenomenologije. Zagreb: Nakladni zavod Globus.

Stallybrass, Peter and Allon White. 2005. Bourgeois Perception: The Gaze and the Contaminating. In: Constance Classen (ed.), The Book of Touch. Oxford: Berg, 289-291.

Stoller, Paul. 1989. The Taste of Ethnographic Things: The Senses in Anthropology. Philadelphia: University of Pennsylvania Press. 
Šikić-Mićanović, Lynette. 2013. Foregrounding the Self in Fieldwork among Rural Women in Croatia. In: Peter Collins and Anselma Gallinat (eds.), The Ethnographic Self as Resource. New York: Oxford: Berghahn Books, 45-62.

Williams, Caroline. 2001. Contemporary French Philosophy: Modernity and the Persistence of the Subject. London: The Athlone Press.

Zlatar, Andrea. 2010. Rječnik tijela: Dodiri, otpor, žene. Zagreb: Naklada Ljevak d.o.o.

\section{OTVORENI SUBJEKT I POVRJEĐUJUĆI SVIJET:} DODIR I OTVARANJE POSTMODERNOG SUBJEKTA

Poziv na potpuni emocionalni, osjetilni i tjelesni angažman na etnografskom terenu koji su iznjedrile postmoderne antropologije poput antropologije tijela $i$ antropologije osjetila, temelji se na ideji da tijelo i tjelesna osjetila mogu pomoći antropologu da izravno doživi i spozna predmet svog istraživanja. Nastale kao pokušaj metodološkog prevladavanja krize reprezentacije u antropologiji, radikalno se angažirajuće metodologije u antropologiji okreću tijelu i osjetilima kao mogućem izlazu iz diskurzivnog kaveza, čime pokušavaju obnoviti autentičnost etnografske prakse.

Kao dio šireg humanističkog poduhvata koji nastoji prevladati naslijeđe moderne, angažirane metodologije nastoje u etnografske svrhe istražiti spoznajne mogućnosti koje se otvaraju u trenutku kad se percepcija oslobodi subjektno-objektne forme. To je perceptivno oslobadanje, inače legitimirano fenomenološkom, posebice Merleau Pontyjevom filozofijom, zasnovano na specifičnoj ontološkoj pretpostavci o tijelu koje sa svijetom i Drugim tvori skladnu cjelinu. Odvojenost od svijeta i Drugih u toj je perspektivi tek nesretan zaostatak kartezijanskog zastranjenja i modernistickih ideja o atomiziranom subjektu koji posjeduje čvrste granice ega. Perceptivna logika moderne, zasnovana na vrijednostima distance i odvojenosti te sorganom vida kao povlaštenim osjetilom, zamijenjena je postmodernističkom ideologijom neposrednosti i dodirom kao temeljnim perceptivnim alatom. $S$ promjenama vrijednosti koje odreduju subjekt $i$ njegov odnos sa svijetom, distanciranost $i$ odvojenost ustupaju mjesto neposrednosti $i$ intimnosti što utječe $i$ na percepciju i vrednovanje dodira kao najneposrednijeg osjetila. Dodir, koji je modernom subjektu opasno i kontaminirajuce osjetilo, tako postaje temeljno osjetilo kojim postmoderni subjekt pristupa svijetu i Drugima. Nastojeći istražiti perceptivne mogućnosti tjelesnog angažmana, 2010. sam pohadao tečaj švedske masaže. Umjesto da ih opovrgne, moje je terensko iskustvo radikalnog tjelesnog angažmana potvrdilo neke modernističke postavke o subjektu. Naime, tijekom mog terenskog rada oslanjanje na tijelo i dodir nisu bili dovoljni da mi osiguraju otvorenost i bliskost spram Drugih. Štoviše, pokazalo se da ni,zatvaranje“ spram Drugih nije u toj mjeri racionalan, koliko tjelesan čin. Potaknut takvim etnografskim iskustvom, u ovom tekstu preispitujem postmodernističku ideju o subjektovoj uronjenosti u svijet $i$ analiziram njene preduvjete. Tu ideju promatram kao imperativ koji slijedi logiku postmodernog stanja. Takav imperativ tijelu ujedno omogućuje kohabitaciju $s$ digitalnim okruženjem karakterističnim za urbanu svakodnevnicu (usp. Livingston 1998) $i$ osigurava prijemčivost organizma za povećan broj podražaja koje proizvodi potrošačko društvo. No, kako bi se subjekt tijelom uspješno otvorio spram svijeta i Drugog potrebna mu je svojevrsna 
ontološka intervencija kojom bi se uklonila svijest o povredi do koje dolazi pri njegovu neposrednom kontaktu sa svijetom. Ta je povreda još od grčke antike konstitutivni temelj subjektova utjelovljivanja i ona odrectuje način na koji je dodir kao najneposrednije osjetilo bio percipiran sve do postmoderne. Ta je povreda, jednako tako, razlog zbog kojeg subjekt moderne zauzima podozriv stav spram svijeta. Naime, svijet narušavanjem subjektovih granica ugrožava njegovu autonomiju. Premda je postmoderni subjekt kritički orijentiran spram granica koje mu je u naslijede ostavila moderna, a koje osim idejne i tjelesne imaju i pravnu i kulturnu dimenziju u vidu pravila koja odrectuju i ograničavaju kontakt izmedu pojedinaca, njegova sklonost otvaranju i intimnosti nastaje ne kao reakcija nego upravo kao rezultat modernističkog socijaliziranja. Upravo sustav zaštite tjelesnog, pravnog i ekonomskog integriteta osobe razvijen na modernom Zapadu omogućuje pojavu subjekta čiji kontakt sa svijetom i Drugima nije obilježen boli i povredom. No, budući da su zahtjevi za pojačanim tjelesnim i osjetilnim angažmanom na etnografskom terenu skloni previdjeti bolni aspekt otvaranja svijetu, kao i kulturnu pozadinu na kojoj nastaju, postavlja se pitanje stvarnog dosega na njima utemeljenih metodoloških paradigmi.

Dr. Petar Bagarić, The Institute of Ethnology and Folklore Research, Šubićeva 42, 10000 Zagreb, Croatia; peroba@ief.hr 